\title{
IMPLEMENTASI CERTAINTY FACTOR UNTUK DIAGNOSA PENYAKIT PARU - PARU
}

\author{
Zulyan Herlani $^{1)}$; Bebas Widada ${ }^{2)}$; Wawan Laksito Yuli Saptomo ${ }^{3)}$ \\ 1) 2) 3) Program Studi Sistem Informasi, STMIK Sinar Nusantara Surakarta \\ ${ }^{1)}$ zulyanherlani2@gmail.com; ${ }^{2}$ bbwdd@gmail.com; ${ }^{3)}$ wlaksito@sinus.ac.id
}

\begin{abstract}
The lungs are one of the most important organs in the human body. Many people today pay less attention to the health of these vital organs. This is evidenced by the many people who consume cigarettes which will have a negative impact on lung health. The lack of public attention to lung health and the high cost of examinations make this problem slow to deal with, by because it requires a system that can be used to diagnose lung disease that can be accessed by the public in general. The Certainty Factor method is a classification algorithm that uses the principles of the assessment of an expert to assess each variable or symptom in each disease in this case and has the accuracy is quite good in conducting data classification, so this method is considered appropriate for diagnosing lung disease based on the symptoms experienced. Data used in this study is expert assessment data on symptoms in each disease, this data is obtained from I interview with pulmonary specialist doctors at Moewardi Hospital Surakarta. The results obtained in this study are the accuracy of the certainty factor algorithm for diagnosing lung disease with diagnostic testing data of 10 data patients with an accuracy of $70 \%$. While the results of functional system testing using the Black Box, it was found that all components of the system have been tested and in accordance with the expected output.
\end{abstract}

Keywords: Diagnose, Certainty Factor, Lung Disease

\section{PENDAHULUAN}

Penyakit paru paru merupakan penyakit yang mengganggu sistem pernafasan khususnya pada manusia. Penyakit paru paru merupakan salah satu penyakit penyebab kematian terbesar setelah penyakit jantung. Penyebab penyakit ini banyak disebabkan oleh virus, stress dan juga asap rokok. Keterbatasan pengetahuan dan mahalnya biaya konsultasi pada dokter spesialis membuat banyak dari penderita penyakit kurang memperhatikan penyakit ini dari gejala - gejala yang dialami. Oleh sebab itu diperlukan sebuah sistem yang dapat diakses secara umum yang dapat digunakan untuk mendiagnosa penyakit paru - paru

Metode klasifikasi seperti naïve bayes, $K$ Nearest Neighbor(KNN), dan C.45 telah digunakan oleh banyak peneliti untuk melakukan diagnosa. Metode Certainty Factor (CF) merupan metode yang diusulkan oleh Shortliffe dan Buchanan pada 1975 untuk mengakomodasi ketidakpastian pemikiran (inexact reasoning) seorang pakar. Seorang pakar sering kali menganalisis informasi yang ada dengan ungkapan seperti "mungkin", "kemungkinan besar", "hampir pasti". Untuk mengakomodasi hal ini kita menggunakan certainty factor (CF) guna menggambarkan tingkat keyakinan pakar terhadap masalah yang sedang dihadapi [1]. Selain itu metode ini dapat memberikan hasil yang akurat yang didapatkan dari perhitungan berdasarkan bobot gejala yang, mampu memberikan jawaban pada permasalahan yang tidak pasti kebenarannya seperti masalah diagnosa resiko penyakit, dan dengan metode ini pakar menggambarkan keyakinan seorang pakar dengan memberikan bobot keyakinan sesuai dengan pengetahuan pakar terkait [2].

Berdasarkan masalah yang telah diuraikan diatas maka pada penelitian ini metode certainty factor akan diterapkan pada sebuah sistem untuk mendiagnosa penyakit paru paru.

\section{TINJAUAN PUSTAKA}

\subsection{Data Mining}

Sistem pakar adalah paket perangkat lunak pengambilan keputusan atau pemecahan masalah yang dapat mencapai tingkat performa yang setara - atau bahkan lebih dengan pakar manusia di beberapa bidang khusus dan biasanya mempersempit area masalah. Menurut Muhammad Arhami, ada beberapa definisi sistem pakar, antara lain [3]:

1. Sistem pakar adalah salah satu cabang dari Artificial Intelligences (Al) yang menggunakan knowledge khusus untuk penyelesaian masalah. 
2. Suatu sistem pakar adalah suatu sistem komputer yang menyamai (emulates) kemampuan pengambilan keputusan dari seorang pakar.

3. Sistem pakar (expert system) merupakan paket perangkat lunak atau paket program komputer yang ditujukan sebagai penyedia nasehat dan sarana bantuan dalam memecahkan masalah di bidang-bidang spesialisasi tertentu seperti sains, prekayasaan, matematika, kedokteran, pendidikan dan sebagainya.

\subsection{Metode Certainty Factor}

Teori Certainty Factor (CF) diusulkan oleh Shortliffe dan Buchanan pada 1975 untuk mengakomodasi ketidakpastian pemikiran (inexact reasoning) seorang pakar. Seorang pakar, (misalnya dokter) sering kali menganalisis informasi yang ada dengan ungkapan seperti "mungkin", "kemungkinan besar", "hampir pasti". Untuk mengakomodasi hal ini kita menggunakan Certainty Factor (CF) guna menggambarkan tingkat keyakinan pakar terhadap masalah yang sedang dihadapi. Ada dua cara dalam mendapatkan tingkat keyakinan (CF) dari sebuah rule Sujoto, T dalam [1].

Dalam mengekspresikan derajat keyakinan, certainty theory menggunakan suatu nilai yang disebut certainty factor (CF) untuk mengasumsikan derajat keyakinan seorang pakar terhadap suatu data. Certainty factor memperkenalkan konsep belief atau keyakinan dan disbelief atau ketidakyakinan. Konsep ini kemudian diformulasikan dalam rumus dasar sebagai berikut[4]:

$\mathrm{CF}(\mathrm{H}, \mathrm{E})=\mathrm{MB}(\mathrm{H}, \mathrm{E})-\mathrm{MD}(\mathrm{H}, \mathrm{E})$

$\mathrm{CF}(\mathrm{H}, \mathrm{E}) \quad$ : Certainty Factor dari hipotesis $\mathrm{H}$ yang dipengaruhi oleh gejala (evidence) E. Besarnya CF berkisar antara -1 sampai 1. Nilai -1 menunjukkan ketidakpercayaan mutlak sedangkan nilai 1 menunjukkan kepercayaan mutlak.

MB $(\mathrm{H}, \mathrm{E})$ :Ukuran kenaikan kepercayaan terhadap hipotesis $\mathrm{H}$ yang dipengaruhi oleh gejala $\mathrm{E}$.

$\mathrm{MD}(\mathrm{H}, \mathrm{E})$ : Ukuran kenaikan ketidakpercayaan terhadap hipotesis $\mathrm{H}$ yang dipengaruhi oleh gejala $\mathrm{E}$.

Kombinasi dua atau lebih aturan (rule) pada sistem berbasis pengetahuan dimana faktor ketidakpastiannya berbeda, maka perhitungan CF (kepercayaan) adalah sebagai berikut:

$\mathrm{CF}(\mathrm{H}, \mathrm{E}) 1,2=\mathrm{CF}(\mathrm{H}, \mathrm{E}) 1+\mathrm{CF}(\mathrm{H}, \mathrm{E}) 2 \times[1-\mathrm{CF}(\mathrm{H}, \mathrm{E}) 1]$

\section{METODE PENELITIAN \\ 3.1 Pengumpulan Data}

1. Data Primer

a) Wawancara

Pengumpulan data dilakukan dengan wawancara secara langsung dengan dokter spesialis paru - paru pada RS Dr.Moewardi Surakarta.

b) Observasi

Pengumpulan data dengan metode observasi ini dilakukan dengan cara menganalisa data-data jenis penyakit dan gejala penyait paru - paru serta data penilaian dari pakar untuk setiap gejala yang dialami yang akan dihitung dengan algoritma certainty factor.

2. Data Sekunder

Studi pustaka dengan mengumpulkan informasi dari jurnal ilmiah, buku - buku dan sumber lainnya yang berkaitan dengan metode certainty factor dan penyakit paru - paru.

\section{HASIL DAN PEMBAHASAN}

\subsection{Persiapan Data}

Pada tahap persiapan ini menggunakan data jenis gejala pada setiap jenis penyakit paru - paru dan dapat penilaian pakar pada masing - masing gejala pada setiap penyakit.

\subsection{Context Diagram}

Context Diagram atau Diagram Konteks adalah hubungan masukan dan keluaran yang menjadi satu kesatuan dalam suatu sistem pada diagram konteks, aliran data dijabarkan secara umum menggambarkan aliran data yang akan di olah dalam sistem informasi. Berikut context diagram dalam sistem diagnosa peyakit paru - paru menggunakan metode certainty factor.

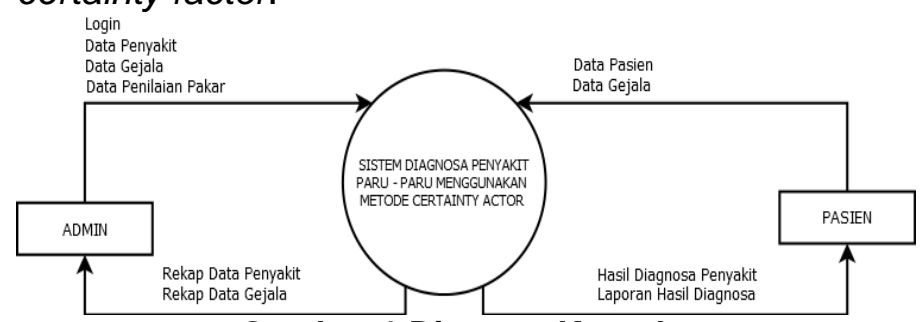

Gambar 1 Diagram Konteks

\subsection{Diagram Alir Data}

Diagram alir data (DAD) adalah teknik penggambaran arah arus data dengan menggunakan simbol - simbol tertentu yang 
telah ditentukan. Berikut DAD level 0 dalam sistem diagnosa penyakit paru - paru menggunakan metode certainty factor.

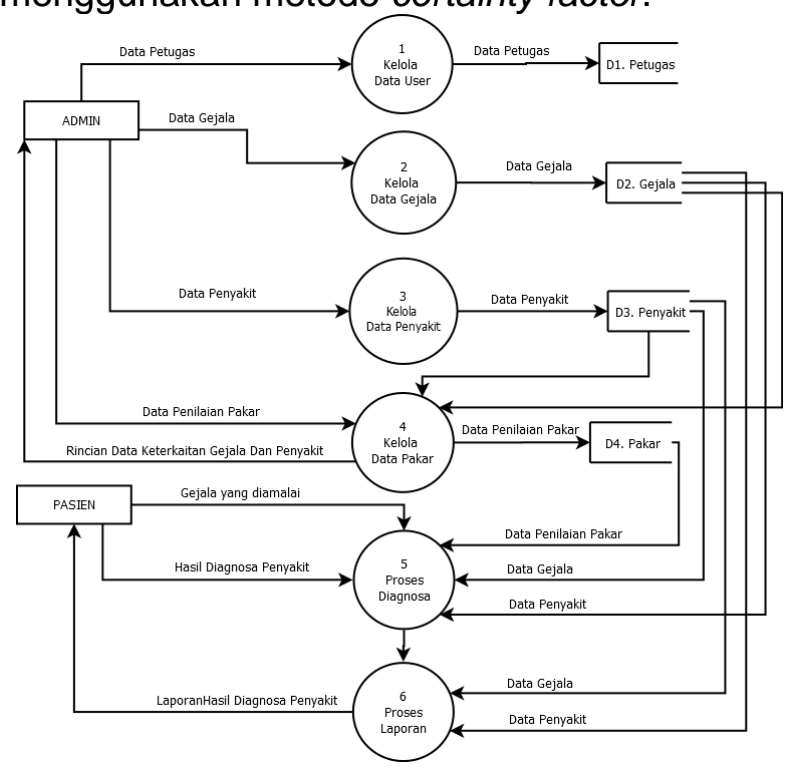

Gambar 2 DFD Level 0

\subsection{ERD}

Sistem diagnosa penyakit paru - paru ini terdapat dua relasi yang berbeda yaitu, relasi yang terjadi pada entitas penyakit dan entitas gejala yang kemudian juga berelasi dengan entitas pasien dimana seluruh entitas mempunyai relasi many to many dengan entitas lainya. Berikut merupakan entity relationship diagram (ERD) pada sistem ini.

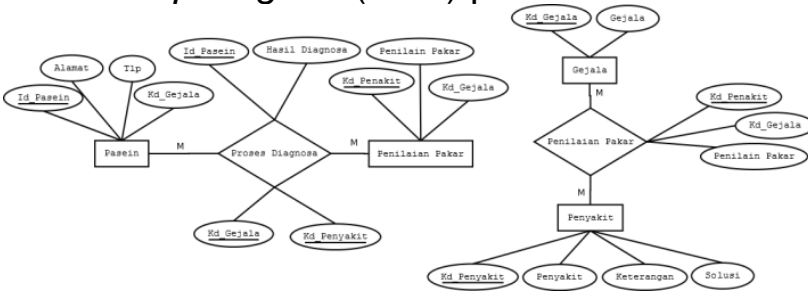

Gambar 3 Entity Relationship Diagam (ERD)

\subsection{Diagram Alir Diagnosa Pasien}

Diagram alir sistem diagnosa penyakit paru - paru menggunakan metode certainty factor dibawah ini menggambarkan secara umum proses diagnosa pada setiap langkah yang ada pada sistem. Proses diagnosa dimulai dengan menginputkan data pasien dan pasien menjawab gejala yang dialami, langkah ke-2 sistem akan menyaring inputan pasien sesuai kaidah yang ditentukan. Langkah berikutnya sistem melakukan komputasi masukan menggunakan metode certainty factor. Langkah terakhir, sistem menampilkan hasil diagnosa penyakit paru - paru sesuai dengan gejala yang diinputkan oleh pasien.

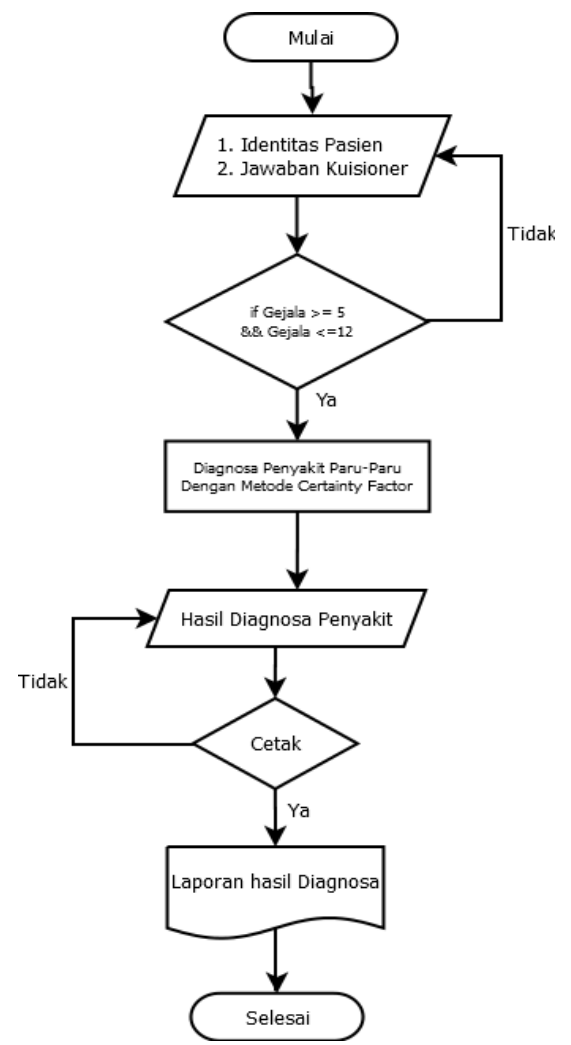

Gambar 4 Flow Chart Proses Diagnosa

\subsection{Perhitungan Diagnosa Algoritma CF}

Data yang digunakan adalah data penilaian pakar terhadap gejala - gejala setiap penyakit paru yang diperoleh dari hasil wawancara dengan dokter spesialis paru - paru di RS Dr. Moewardi Surakarta.

1. Contoh Kasus

Seorang pasien mengalami keluhan dengan gejala - gejala sebagai berikut :

- Kelelahan

- Warna kulit kebiru - biruan

- Denyut jantung cepat

- Sering menderita infeksi pernafasan

- Pembengkakan pada pergelangan kaki

- Wajah, Telapak Tangan atau Selaput Lender Berwarna Kemerah Merahan

- Sakit kepala

- Pipi kemerahan

2. Memperkirakan Penyakit dari Gejala yang Dialami Pasien.

Berdasarkan gejala - gejala yang dialami oleh pasien diatas, maka dapat diperkirakan pasien mengalami penyakit paru - paru dengan dugaan seperti dijelaskan pada Tabel 1.

Tabel 1. Dugaan Penyakit

\begin{tabular}{|c|l|}
\hline $\mathbf{1}$ & Pneumotoraks \\
\hline G014 & Kelelahan \\
\hline G015 & Warna Kulit Kebiru - biruan \\
\hline G016 & Denyut Jantung Cepat \\
\hline
\end{tabular}




\begin{tabular}{|c|l|}
\hline $\mathbf{2}$ & Bronkitis \\
\hline G017 & Sering Menderita Infeksi Pernafasan \\
\hline G018 & Pembekakan pada pergelangan kaki \\
\hline G019 & $\begin{array}{l}\text { Wajah, telapak tangan atau selaput lender } \\
\text { berwarna kemerah merahan }\end{array}$ \\
\hline G020 & Pipi Kemerahan \\
\hline G021 & Sakit Kepala \\
\hline $\mathbf{3}$ & Kanker Paru - Paru \\
\hline G014 & Kelelahan \\
\hline G021 & Sakit Kepala \\
\hline
\end{tabular}

3. Menentukan Nilai Evidence (E)

Langkah berikutnya adalah menentukan nilai Evidence atau bobot dari setiap gejala. Pengguna diberikan pilihan jawaban yang masing - masing bobotnya ditunjukkan pada Tabel 2.

Tabel 2 Nilai Evidence (E)

\begin{tabular}{|c|c|}
\hline Keyakinan & CF \\
\hline Tidak & 0 \\
\hline Tidak Tahu & 0.2 \\
\hline Sedikit Yakin & 0.4 \\
\hline Cukup Yakin & 0.6 \\
\hline Yakin & 0.8 \\
\hline Sangat Yakin & 1 \\
\hline
\end{tabular}

4. Menentukan Nilai Hipotesis $(\mathrm{H})$

Langkah selanjutnya setelah menentukan nilai evidence adalah menentukan hipotesis atau nilai CF pada masing - masing gejala pada setiap jenis penyakit yang telah ditentukan berdasarkan wawancara dengan pakar atau dokter ahli paru - paru yang disajikan pada Tabel 3.

Tabel 3 Nilai Hipotesis (H)

\begin{tabular}{|c|c|c|c|c|}
\hline No & Penyakit & Kode & Gejala & $\begin{array}{l}\text { Nilai } \\
\text { CF }\end{array}$ \\
\hline \multirow[t]{7}{*}{1} & \multirow[t]{7}{*}{ Pneumonia } & G001 & Batuk Berdahak & 0.8 \\
\hline & & G002 & Sakit Pada Dada & 0.4 \\
\hline & & G003 & Sesak Nafas & 0.8 \\
\hline & & G004 & Demam Tinggi & 0.8 \\
\hline & & G005 & Banyak Berkeringat & 0.4 \\
\hline & & G006 & Mual dan Muntah & 0.4 \\
\hline & & G007 & Diare & 0.4 \\
\hline \multirow[t]{8}{*}{2} & \multirow[t]{8}{*}{ TBC } & G001 & Batuk Berdahak & 0.8 \\
\hline & & G008 & $\begin{array}{l}\text { Batuk Berdahak } \\
\text { disertai Darah }\end{array}$ & 0.8 \\
\hline & & G003 & Sesak Nafas & 0.6 \\
\hline & & G009 & $\begin{array}{l}\text { Badan Terasa } \\
\text { Lemah }\end{array}$ & 0.4 \\
\hline & & G010 & $\begin{array}{l}\text { Penurunan Nafsu } \\
\text { Makan }\end{array}$ & 0.8 \\
\hline & & G011 & $\begin{array}{l}\text { Perasaan Tidak } \\
\text { Enak }\end{array}$ & 0.4 \\
\hline & & G012 & $\begin{array}{l}\text { Penurunan Berat } \\
\text { Badan }\end{array}$ & 0.8 \\
\hline & & G013 & $\begin{array}{l}\text { Demam Pada Siang } \\
\text { dan Sore Hari }\end{array}$ & 0.6 \\
\hline \multirow[t]{5}{*}{3} & \multirow[t]{5}{*}{ Pneumotoraks } & G002 & Sakit Pada Dada & 0.6 \\
\hline & & G003 & Sesak Nafas & 0.8 \\
\hline & & G014 & Kelelahan & 0.6 \\
\hline & & G015 & $\begin{array}{l}\text { Warna Kulit Kebiru - } \\
\text { biruan }\end{array}$ & 0.6 \\
\hline & & G001 & Batuk Berdahak & 0.4 \\
\hline
\end{tabular}

\begin{tabular}{|c|c|c|c|c|}
\hline No & Penyakit & Kode & Gejala & $\begin{array}{l}\text { Nilai } \\
\text { CF }\end{array}$ \\
\hline & & G016 & $\begin{array}{l}\text { Denyut Jantung } \\
\text { Cepat }\end{array}$ & 0.6 \\
\hline \multirow[t]{8}{*}{4} & \multirow[t]{8}{*}{ Bronkitis } & G003 & Sesak Nafas & 0.4 \\
\hline & & G001 & Batuk Berdahak & 0.6 \\
\hline & & G009 & $\begin{array}{l}\text { Badan Terasa } \\
\text { Lemah }\end{array}$ & 0.4 \\
\hline & & G017 & $\begin{array}{l}\text { Sering Menderita } \\
\text { Infeksi Pernafasan }\end{array}$ & 0.8 \\
\hline & & G018 & $\begin{array}{l}\text { Pembekakan pada } \\
\text { pergelangan kaki }\end{array}$ & 0.4 \\
\hline & & G019 & $\begin{array}{l}\text { Wajah, telapak } \\
\text { tangan atau selaput } \\
\text { lender berwarna } \\
\text { kemerah merahan }\end{array}$ & 0.4 \\
\hline & & G020 & Pipi Kemerahan & 0.4 \\
\hline & & G021 & Sakit Kepala & 0.4 \\
\hline & & G022 & $\begin{array}{l}\text { Gangguan } \\
\text { Penglihatan }\end{array}$ & 0.4 \\
\hline \multirow[t]{6}{*}{5} & \multirow[t]{6}{*}{ Emfisema } & G003 & Sesak Nafas & 0.8 \\
\hline & & G010 & $\begin{array}{l}\text { Nafsu Makan } \\
\text { Berkurang }\end{array}$ & 0.6 \\
\hline & & G012 & $\begin{array}{l}\text { Penurunan Berat } \\
\text { Badan }\end{array}$ & 0.6 \\
\hline & & G023 & Batuk & 0.8 \\
\hline & & G024 & $\begin{array}{l}\text { Suara Mengi Saat } \\
\text { Bernafas }\end{array}$ & 0.8 \\
\hline & & G025 & $\begin{array}{l}\text { Bibir dan Kuku } \\
\text { Berwarna Biru }\end{array}$ & 0.4 \\
\hline \multirow[t]{7}{*}{6} & \multirow[t]{7}{*}{ Asma } & G003 & Sesak Nafas & 0.8 \\
\hline & & G024 & $\begin{array}{l}\text { Suara Mengi Saat } \\
\text { Bernafas }\end{array}$ & 0.8 \\
\hline & & G026 & $\begin{array}{l}\text { Produksi Lender } \\
\text { Berlebihan }\end{array}$ & 0.6 \\
\hline & & G027 & $\begin{array}{l}\text { Serangan terjadi } 3- \\
4 \times \text { setahun }\end{array}$ & 0.6 \\
\hline & & G028 & $\begin{array}{l}\text { Gejala Timbul } \\
\text { dimalam hari }\end{array}$ & 0.6 \\
\hline & & G023 & Batuk & 0.8 \\
\hline & & G029 & $\begin{array}{l}\text { Susah Tidur } \\
\text { (Insomnia) }\end{array}$ & 0.4 \\
\hline \multirow[t]{5}{*}{7} & \multirow[t]{5}{*}{ Efusi Pleura } & G030 & Nyeri Dada & 0.6 \\
\hline & & G003 & Sesak Nafas & 0.8 \\
\hline & & G001 & Batuk Berdahak & 0.4 \\
\hline & & G004 & Demam & 0.4 \\
\hline & & G031 & Sering Cegukan & 0.4 \\
\hline \multirow[t]{7}{*}{8} & \multirow[t]{7}{*}{ Fibrosis Kistik } & G032 & $\begin{array}{l}\text { Batuk } \\
\text { Berkepanjangan }\end{array}$ & 0.6 \\
\hline & & G003 & Sesak Nafas & 0.8 \\
\hline & & G007 & Diare & 0.4 \\
\hline & & G006 & Mual dan Muntah & 0.4 \\
\hline & & G033 & Nafas Pendek & 0.4 \\
\hline & & G024 & $\begin{array}{l}\text { Suara Mengi Saat } \\
\text { Bernafas }\end{array}$ & 0.8 \\
\hline & & G034 & $\begin{array}{l}\text { Saluran Udara } \\
\text { Melebar Akibat } \\
\text { Peradangan }\end{array}$ & 0.8 \\
\hline \multirow[t]{10}{*}{9} & \multirow{10}{*}{$\begin{array}{c}\text { Kanaker Paru } \\
\text { - Paru }\end{array}$} & G008 & Batuk Berdarah & 0.8 \\
\hline & & G030 & Nyeri Dada & 0.8 \\
\hline & & G032 & $\begin{array}{l}\text { Batuk } \\
\text { Berkepanjangan }\end{array}$ & 0.8 \\
\hline & & G003 & Sesak Nafas & 0.8 \\
\hline & & G014 & Kelelahan & 0.4 \\
\hline & & G035 & Asma & 0.4 \\
\hline & & G021 & Sakit Kepala & 0.4 \\
\hline & & G036 & $\begin{array}{l}\text { Gangguan } \\
\text { Keseimbangan }\end{array}$ & 0.4 \\
\hline & & G037 & $\begin{array}{l}\text { Mati Rasa Pada } \\
\text { Tungkai }\end{array}$ & 0.4 \\
\hline & & G038 & $\begin{array}{l}\text { Mata dan Kulit } \\
\text { Menguning } \\
\end{array}$ & 0.4 \\
\hline
\end{tabular}


5. Menentukan Nilai Bobot User

Langkah berikutnya adalah menentukan nilai keyakinan dari user. Nilai CF ditentukan untuk setiap gejala dalam range nilai 0 sampai dengan 1 dan nilai ini mewakili keyakinan seorang pasien. Pada sistem akan disediakan form pertanyaan untuk masalah ini. Adapun bobot keyakinan dari pasien terhadap gejala - gejala yang dialami ditampilkan pada Tabel 4 .

Tabel 4 Nilai Keyakinan Pasien

\begin{tabular}{|l|l|l|r|}
\hline KODE & \multicolumn{1}{|c|}{ GEJALA } & KEYAKINAN & NILAI \\
\hline G014 & Kelelahan & Cukup Yakin & 0.6 \\
\hline G015 & Wama Kulit Kebiru - biruan & Cukup Yakin & 0.6 \\
\hline G016 & Denyut Jantung Cepat & Sangat Yakin & 1 \\
\hline G017 & Sering Menderita Infeksi Pemafasan & Sangat Yakin & 1 \\
\hline G018 & Pembekakan pada Pergelangan Kaki & Cukup Yakin & 0.6 \\
\hline G019 & $\begin{array}{l}\text { Wajah, Telapak Tangan atau Selaput } \\
\text { Lender Berwama Kemerah Merahan }\end{array}$ & Cukup Yakin & 0.6 \\
\hline G020 & Pipi Kemerahan & Sangat Yakin & 1 \\
\hline G021 & Sakit Kepala & Sangat Yakin & 1 \\
\hline
\end{tabular}

6. Menghitung Nilai CF

Langkah berikutnya setelah menentukan adalah menghitung nilai CF, dari kaidah kaidah atau rule yang telah ditentukan kemudian dihitung nilai CF dengan mengalikan nilai $\mathrm{CF}$ user dengan nilai CF pakar.

a. Pneumotoraks

$$
\begin{aligned}
\mathrm{CF}[\mathrm{H}, \mathrm{E}] 1 & =\mathrm{CF}[\mathrm{H}] 1 \times \mathrm{CF}[\mathrm{E}] 1 \\
& =0,6 \times 0,6 \\
& =0,36 \\
\mathrm{CF}[\mathrm{H}, \mathrm{E}] 2 & =\mathrm{CF}[\mathrm{H}] 2 \times \mathrm{CF}[\mathrm{E}] 2 \\
& =0,6 \times 0,6 \\
& =0,36 \\
\mathrm{CF}[\mathrm{H}, \mathrm{E}] 3 & =\mathrm{CF}[\mathrm{H}] 3 \times \mathrm{CF}[\mathrm{E}] 3 \\
& =1,0 \times 0,6 \\
& =0,6
\end{aligned}
$$

b. Bronkitis

$$
\begin{aligned}
\mathrm{CF}[\mathrm{H}, \mathrm{E}] 1 & =\mathrm{CF}[\mathrm{H}] 1 \times \mathrm{CF}[\mathrm{E}] 1 \\
& =1,0 \times 0,8 \\
\mathrm{CF}[\mathrm{H}, \mathrm{E}] 2 & =0,8 \\
& =0,6 \times 0,4 \\
& =0,24 \\
\mathrm{CF}[\mathrm{H}, \mathrm{E}] 3 & =\mathrm{CF}[\mathrm{H}] 3 \times \mathrm{CF}[\mathrm{E}] 3 \\
& =0,6 \times 0,4 \\
& =0,24 \\
\mathrm{CF}[\mathrm{H}, \mathrm{E}] 4 & =\mathrm{CF}[\mathrm{H}] 4 \times \mathrm{CF}[\mathrm{E}] 4 \\
& =1,0 \times 0,4 \\
& =0,4 \\
\mathrm{CF}[\mathrm{H}, \mathrm{E}] 5 & =\mathrm{CF}[\mathrm{H}] 5 \times \mathrm{CF}[\mathrm{E}] 5 \\
& =1,0 \times 0,4 \\
& =0,4
\end{aligned}
$$

c. Kanker Paru - Paru

$$
\begin{aligned}
\mathrm{CF}[\mathrm{H}, \mathrm{E}] 1 & =\mathrm{CF}[\mathrm{H}] 1 \times \mathrm{CF}[\mathrm{E}] 1 \\
& =0,6 \times 0,4 \\
& =0,24 \\
\mathrm{CF}[\mathrm{H}, \mathrm{E}] 2 & =\mathrm{CF}[\mathrm{H}] 2 \times \mathrm{CF}[\mathrm{E}] 2 \\
& =1,0 \times 0,4 \\
& =0,4
\end{aligned}
$$

7. Menghitung Nilai CF Kombinasi

Mengkombinasikan nilai CF (menentukan nilai CF combin) dari masing - masing kaidah atau rule terhadap masing masing gejala pada setiap dugaan penyakit.

a. Pneumotoraks.

$$
\begin{aligned}
\text { CFcomb } \mathrm{CF}[\mathrm{H}, \mathrm{E}] 1,2= & \mathrm{CF}[\mathrm{H}, \mathrm{E}] 1+\mathrm{CF}[\mathrm{H}, \mathrm{E}] 2 \times(1- \\
& =0,36+0,36 \times(1-0,36) \\
& =0,59(\text { Old } 1)
\end{aligned}
$$

CFcomb CF[H,E]Old1,3= CF[H,E]Old1 + CF[H,E] $3 \times(1$ - $\mathrm{CF}[\mathrm{H}, \mathrm{E}] \mathrm{Old} 1)$

$$
\begin{aligned}
& =0,59+0,6 \times(1-0,59) \\
& =0,836(\text { Old } 2) \\
& =0,836 \times 100 \% \\
& =83,6 \%
\end{aligned}
$$$$
\text { Nilai Diagnosa } \quad=0,836 \times 100 \%
$$

Berdasarkan perhitungan diagnose dengan metode certainty factor dapat diketahui bahwa dengan gejala - gejala yang dialami pasien maka kemungkinan pasien mengalami penyakit Pneumotoraks adalah 83,6\%

b. Bronkitis

CFcomb CF[H,E]1,2 = CF[H,E]1 + CF[H,E]2 x 1 $\mathrm{CF}[\mathrm{H}, \mathrm{E}] 1$

$$
\begin{aligned}
& =0,8+0,24 \times(1-0,8) \\
& =0,848 \text { (Old } 1)
\end{aligned}
$$

CFcomb CF[H,E]Old1,3= CF[H,E]Old1 + CF[H,E] $3 \times(1$ - CF[H,E]Old1)

$$
=0,848+0,24 \times(1-0,848)
$$$$
=0,88488(\text { Old } 2)
$$

CFcomb CF[H,E]Old2,4= CF[H,E]Old2 + CF[H,E] $4 \times(1$ - CF[H,E]Old2)

$$
=0,88488+0,4 \times(1-0,88488)
$$$$
=0,930688(\mathrm{Old} 3)
$$

CFcomb CF[H,E]Old3,5= CF[H,E]Old3 $+\mathrm{CF}[\mathrm{H}, \mathrm{E}] 5 \times(1$ - CF[H,E]Old3)

$0,930688)$

$$
\begin{array}{ll} 
& =0,9584128(\text { Old } 4) \\
\text { Nilai Diagnosa } & =0,9584128 \times 100 \% \\
& =95,84128 \%
\end{array}
$$

Berdasarkan perhitungan diagnosa dengan metode certainty factor dapat diketahui bahwa dengan gejala - gejala yang dialami pasien maka kemungkinan pasien mengalami penyakit Bronkitis adalah 95,84128\%

c. Kanker Paru - Paru.

CFcomb CF[H,E]1,2 = $(\mathrm{CF}[\mathrm{H}, \mathrm{E}] 1+\mathrm{CF}[\mathrm{H}, \mathrm{E}] 2) \times(1-$ 


$\begin{aligned} & =0,24+0,4 \times(1-0,24) \\ & =0,544(\text { Old } 1) \\ \text { Nilai Diagnosa } & =0,544 \times 100 \% \\ & =54,4 \%\end{aligned}$

Berdasarkan perhitungan diagnosa dengan metode certainty factor dapat diketahui bahwa dengan gejala - gejala yang dialami pasien maka kemungkinan pasien mengalami penyakit Kanker paru paru adalah $54,4 \%$

8. Hasil Diagnosa

Bedasarkan perhitungan diagnosa yang telah dilakukan terhadap pasien dengan gejala - gejala yang dialami maka dapat disimpulkan bahwa pasien menderita penyakit Bronkitis dengan kemungkinan positif 95,84128\%.

\subsection{Implementasi}

1. Halaman Beranda.

Halaman beranda adalah halaman pertama yang ditampilkan sistem tanpa harus melakukan login (Gambar 5).

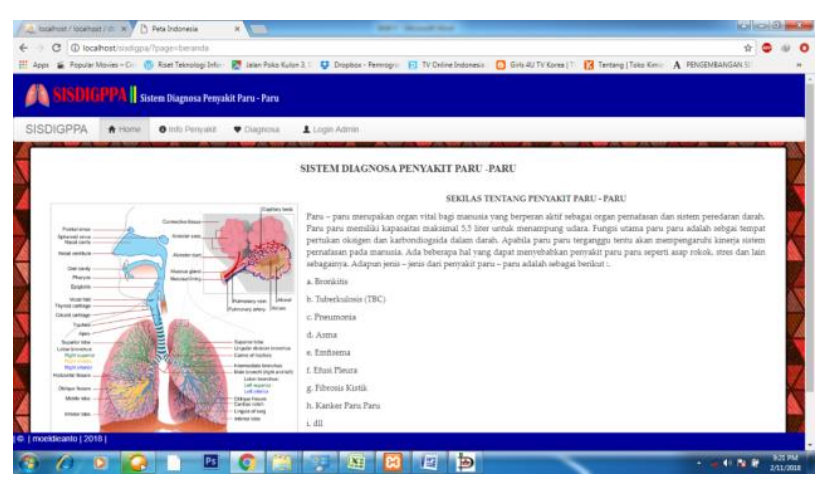

Gambar 5 Halaman Beranda

2. Halaman Data Diri Pasien.

Untuk melakukan diagnosa pasien harus melengkapi seluruh data diri. Adapun halaman data diri pada sistem ini ditunjukkan pada Gambar 6.

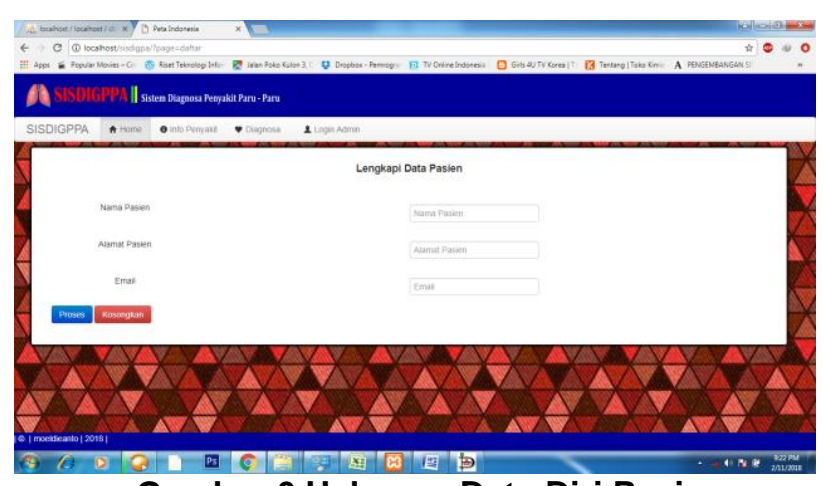

Gambar 6 Halaman Data Diri Pasien
3. Halaman Inputan Kuisioner.

Pada halaman ini tersedia daftar pertanyaan yang harus dijawab oleh pasien sesuai gejala - gejala yang dialami oleh pasien untuk melakukan proses diagnosa. Berikut merupakan tampilan halaman kuisioner (Gambar 7).

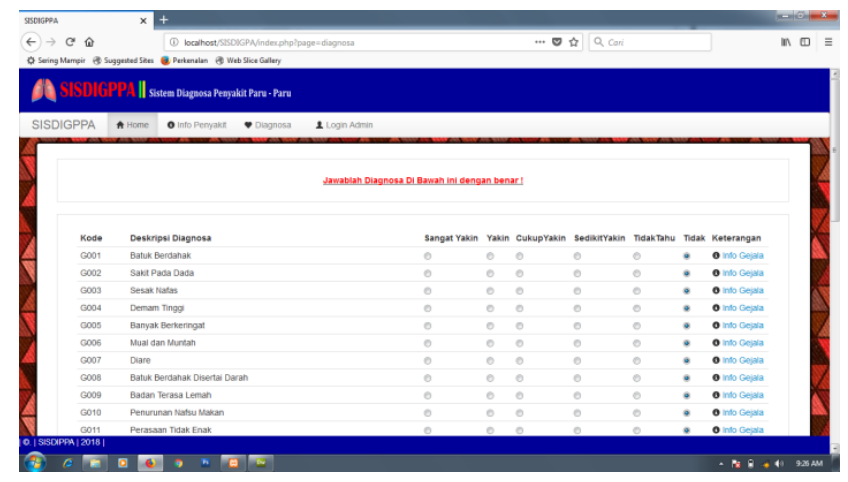

Gambar 7 Halaman Kuisioner

4. Halaman Hasil Diagnosa.

Halaman ini akan menampilkan hasil data diri pasien, gejala - gejala yang dialami pasien dan hasil diagnosa pasien berupa jenis penyakit yang dialami. Pada halaman ini juga menampilkan menu untuk mencetak hasil diagnosa (Gambar 8).

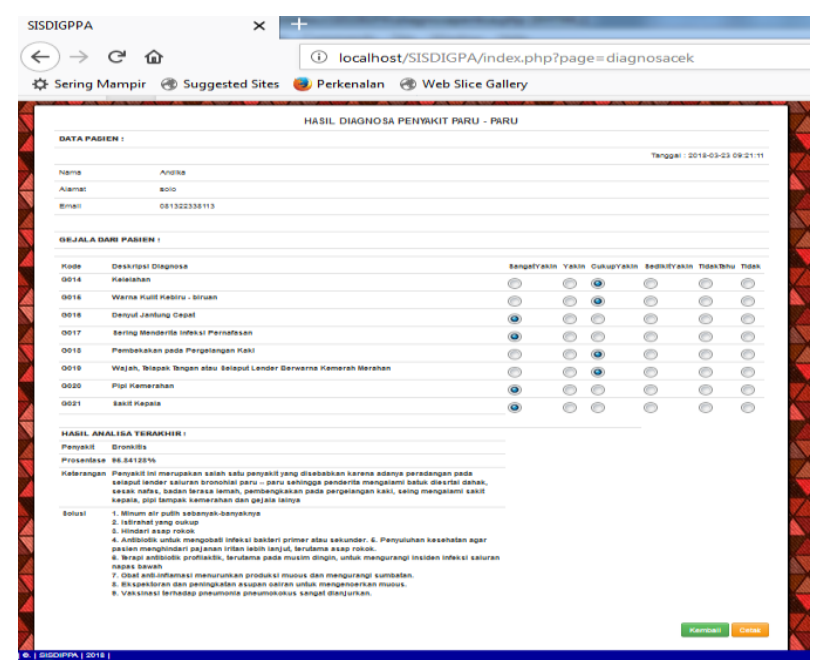

Gambar 8 Halaman Hasil Diagnosa

5. Halaman Laporan Hasil Diagnosa

Halaman ini akan menampilkan hasil diagnosa dalam bentuk laporan yang dapat langsung dicetak atau di download dalam bentuk PDF (Gambar 9). 


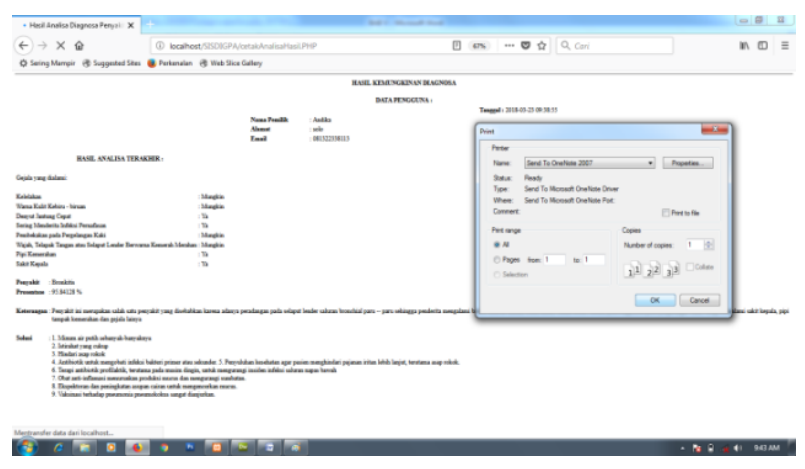

Gambar 9 Halaman Laporan

6. Halaman Login Admin

Untuk mengelola data yang yang digunakan untuk diagnosa maka user harus melakukan login untuk mengakses menu administrator (Gambar 10).

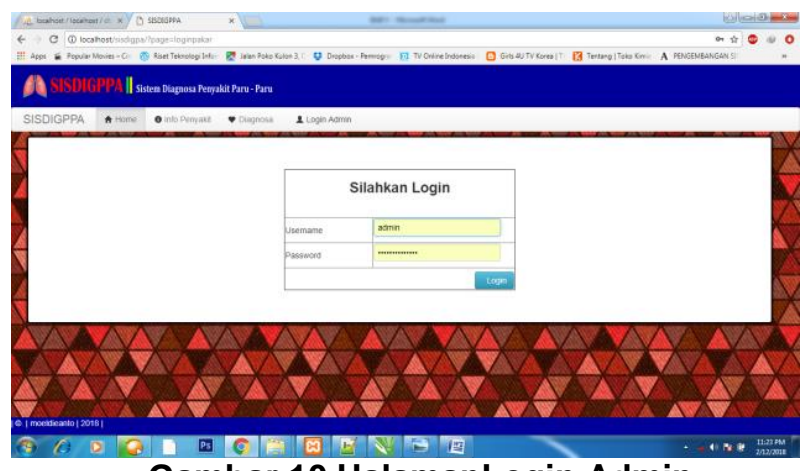

Gambar 10 HalamanLogin Admin

7. Halaman Kelola Data Gejala.

Menu pertama pada halaman admin adalah menu kelola data gejala. Pada halaman ini admin dapat melakukan operasi input, edit dan hapus pada data gejala yang terdaftar pada sistem (Gambar 11).

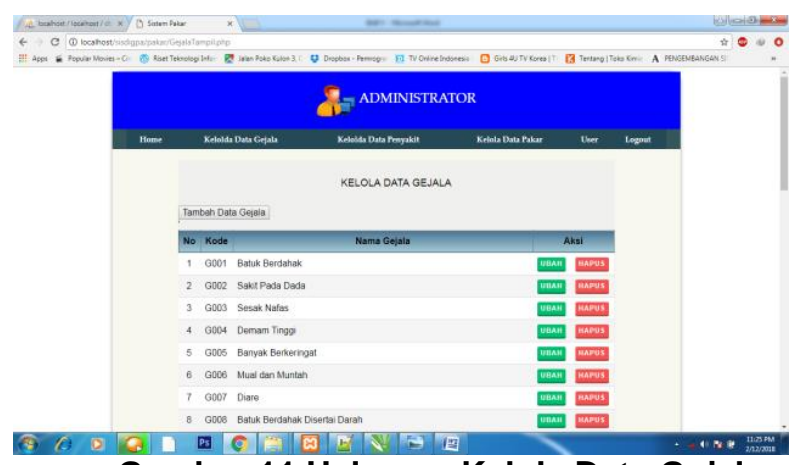

Gambar 11 Halaman Kelola Data Gejala

8. Halaman Kelola Data Penyakit.

Menu berikutnya pada halaman admin adalah menu kelola data penyakit. Pada halaman ini admin dapat melakukan operasi input, edit dan hapus pada data penyakit yang terdaftar pada sistem (Gambar 12).

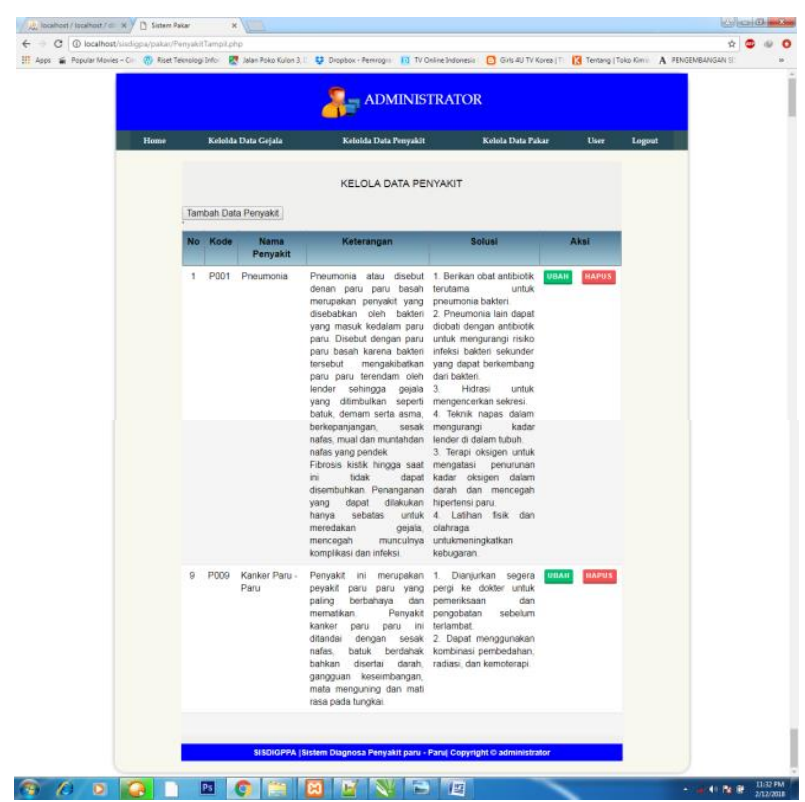

Gambar 12 Halaman Kelola Data Penyakit

9. Halaman Update Data Penilaian Pakar.

Halaman ini jenis penyakit beserta gejala - gejalanya.Pada halaman ini admin dapat mengapdate penilaian pakar untuk setiap gejala pada setiap penyakit yang terdaftar pada sistem (Gambar 13).

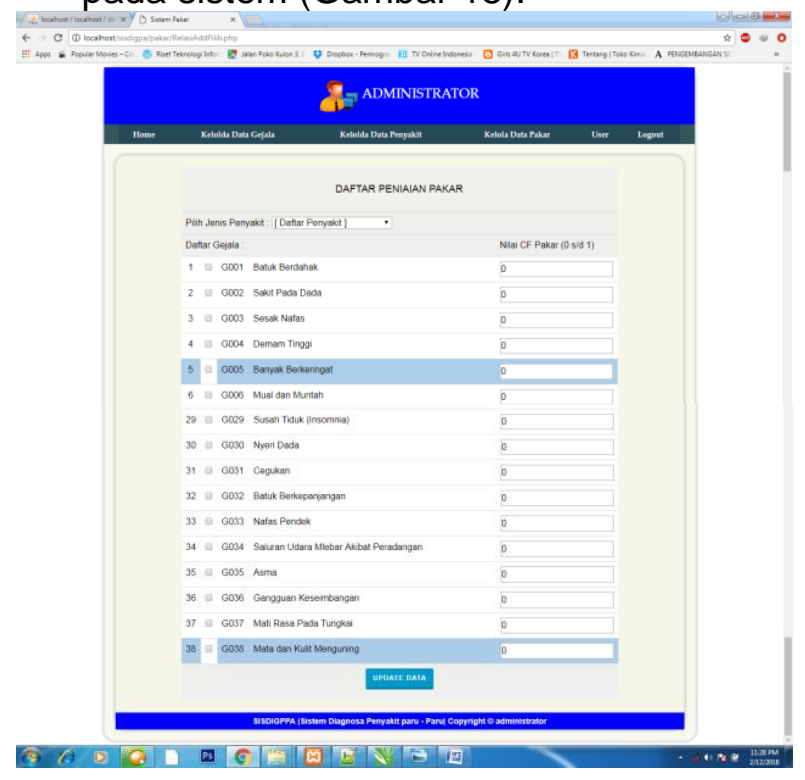

Gambar 13 Halaman Kelola Data Pakar

\section{KESIMPULAN DAN SARAN}

\subsection{Kesimpulan}

Berdasarkan pembahasan mengenai penerapan algoritma certainty factor untuk diagnosa penyakit paru - paru maka dapat disimpulkan:

1. Telah terciptanya Sistem Diagnosa Penyakit Paru - Paru Menggunakan Algoritma Certainty Factor dengan studi 
kasus pada RS Dr. Moewardi Surakarta. Sehingga dapat digunakan untuk melakuan diagnosa pada pasien berdasarkan gejala - gejala yang dialami.

2. Melalui pengujian validitas menggunakan membandingkan hasil diagnosa sistem dengan data uji yang ada, maka didapatkan tingkat akurasi untuk algoritma Certainty Factor adalah $70 \%$ dari 10 data uji yang ada.

3. Melalui uji fungsional sistem dengan metode Black Box Testing dengan hasil seluruh komponen sistem telah sesuai kriteria yang direncanaan maka dapat disimpulkan sistem ini dapat digunakan oleh RS Dr. Moewardi Surakarta dan masyarakat pada umumnya untuk melakukan diagnosa penyakit paru - paru yang diderita berdasarkan gejala - gejala yang dialami oleh pasien.

\subsection{Saran}

1. Pada penelitian berikutnya prediksi disarankan untuk menambahkan variabel - variabel yang lebih kompleks seperti usia dan jenis kelamin untuk lebih meningkatkan akurasi dari metode certainty factor.

2. Pada penelitian berikutnya disarankan untuk melakukan diagnosa penyakit paru paru menggunakan metode lain seperti Suport Vertor Machine (SVM) atau Naïve Bayes untuk mengetahui tingkat akurasi terbaik untuk melakukan diagnosa penyakit paru - paru.

\section{DAFTAR PUSTAKA}

[1] Larasati Tutur and Muhammad Aref, "Sistem Pakar Diagnosa Awal Penyakit Kulit Kucing Berbasis Web Menggunakan Metode Certainty Factor (Studi Kasus: Lab Klinik "Klinik Hewan Jogja," Semnasteknomedia Online, pp. 3-4, 2016.

[2] Stephanie Halim and Seng Hansun, "Penerapan Metode Certainty Factor dalam Sistem Pakar Pendeteksi Resiko Osteoporosis dan Osteoarthritis," ISSN 2355-3286, p. 1, 2016.

[3] M. Arhami, "Konsep Dasar Sistem Pakar," Andi, Yogyakarta, 2005.

[4] Fitriyati and Dwi Ajeng Sasmitha, "Sistem Pakar Untuk Mendiagnosa Jenis Dyslexia Menggunakan Certainty Factor," Semnasteknomedia Online, vol. 4, p. 6, 2016.
[5] Sujoto T, Kecerdasan Buatan., Andi, Yogyakarta, 2011. 